\title{
Volume 29 Part 1
}

SPECIAL ISSUE

Robotic Self-X Systems

GUEST EDITORS

Dr. Amor Menezes and

Prof. Pierre Kabamba

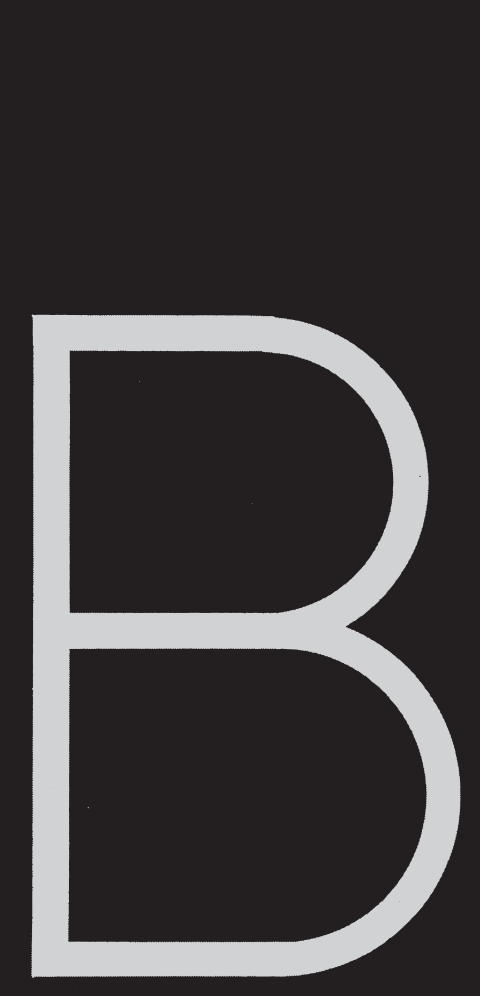

d
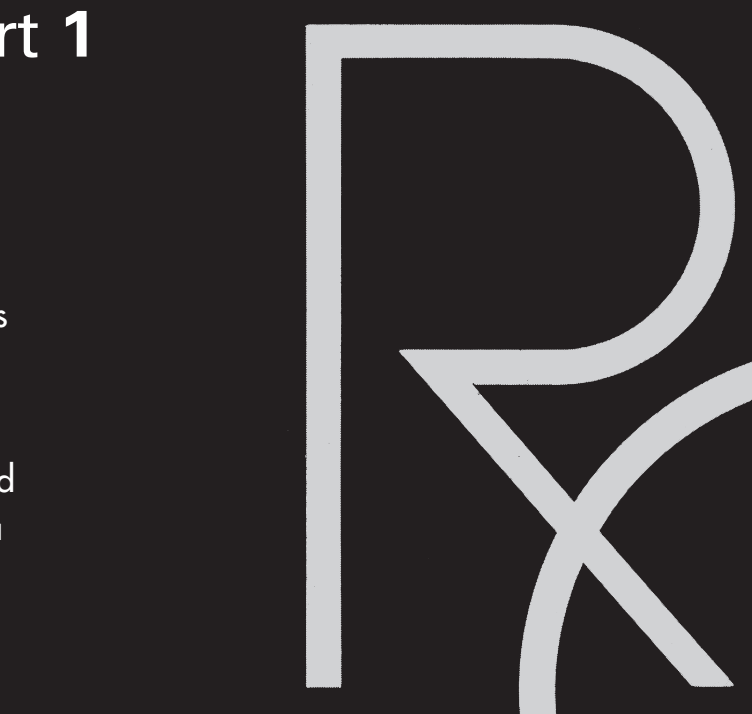

International Journal of

Information, Education and

Research in Robotics and Artificial Intelligence

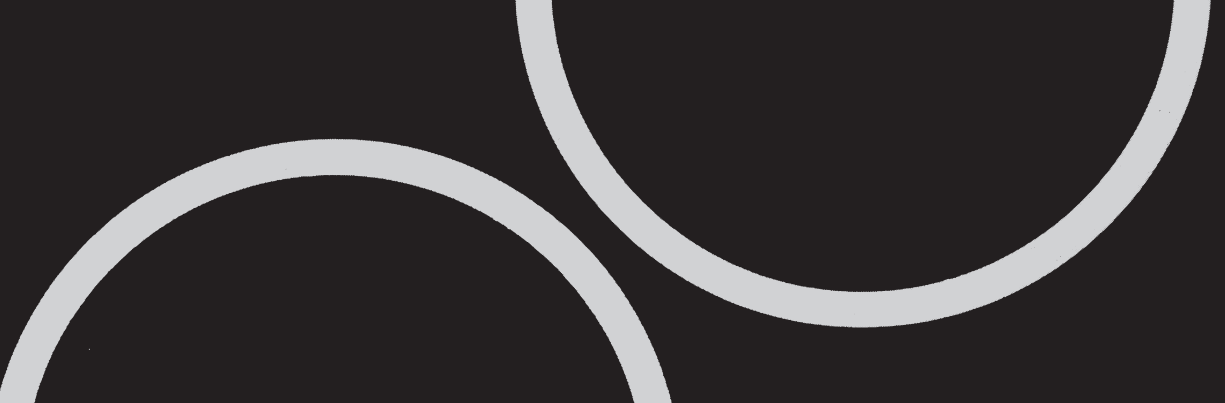


International Journal of Information, Education and Research in Robotics and Artificial Intelligence

\section{EDITOR}

Professor G.S. Chirikjian, Department of Mechanical Engineering,

Johns Hopkins University, 223 Latrobe Hall, 3400 N. Charles Street,

Baltimore MD 21218-2686, USA

E-mail:gregc@jhu.edu

\section{Associate EDITORS}

Professor Fabrizio Caccavale, Università degli Studi della Basilicata, Potenza, Italy (E-mail: caccavale@unibas.it)

Professor Jian S. Dai, King's College London, University of London, UK (E-mail: jian.dai@kcl.ac.uk)

Professor Todd D. Murphey, Northwestern University, Evanston, Illinois, USA (E-mail: t-murphey@northwestern.edu)

Professor Giuseppe Carbone, University of Cassino (E-mail: carbone@unicas.it)

FOUNDING EDITOR

Professor J. Rose, $(U K)$

\section{EDITORIAL BOARD}

Dr G.K. Ananthasuresh, The Indian Institute of Science, Bangalore, India

Professor T. Bock, Technical University, Munich, Germany

Professor I-Ming Chen, Nanyang Technological University, Singapore

Professor H.S. Cho, Advanced Institute of Science and Technology, South Korea

Professor Howie Choset, Carnegie Mellon University, Pittsburgh, USA

Professor S. Hirose, Tokyo Institute of Technology, Japan

Dr M. Kassler, Michael Kassler \& Associates, Pty, NSW, Australia

Professor G. Liu, Ryerson University, Canada

Professor F. Miyazaki, Ozaka University, Japan

Professor G. Pennock, Purdue University, USA

Robotica aims to be an outlet for publication of original papers of the highest quality in the field of Robotics and closely related areas. This includes: novel robotic mechanism and actuator design; robot kinematics, dynamics and control; computer vision; sensor fusion; teleoperation and haptic interfaces; robot motion planning; and artificial intelligence. In addition, papers that apply techniques from Robotics to other fields are also welcome. Examples include dynamics and control models applied to biological systems, the description of implementations of robots in factories, service and agricultural settings, and general mechatronic design. Works may be theoretical, computational or experimental, or some combination. Both short papers (rapid communications), and longer archival papers are welcome. Proposals for special issues on topics of current interest are welcome, and can be submitted via email to the editor.

This journal issue has been printed on FSC-certified paper and cover board. FSC is an independent, non-governmental, not-for-profit organization established to promote the responsible management of the world's forests. Please see www.fsc.org for information.

(C) Cambridge University Press 2011

SUBSCRIPTIONS

Robotica (ISSN 0263-5747) is published as seven Issues per Volume in January, March, May, July, September, October and December. The subscription price which includes print and electronic access (excluding VAT but includes postage) of Volume 29, 2011 is £700 net (US $\$ 1250$ in USA, Canada and Mexico) for institutions and $£ 175$ (US $\$ 300$ in USA, Canada and Mexico) for individuals certifying that the Journal is for their personal use. The electronic-only price available to institutional subscribers is $£ 615$ (US $\$ 1100$ in USA, Canada and Mexico). Single parts cost £106 net (US \$198 in USA, Canada and Mexico) plus postage. Seven parts form a volume. EU subscribers (outside the UK) who are not registered for VAT should add VAT at their
Professor D.T. Pham, University of Wales, UK

Professor B. Roth, Stanford University, USA

Professor R.D. Schraft, Fraunhofer-Institut, Stuttgart, Germany

Dr J. M. Selig, London South Bank University, UK

Professor B. Siciliano, University of Naples, Italy

Professor J. Trevelyan, University of Western Australia, Australia

Professor Jeff Trinkle, Rensselaer Polytechnic Institute, USA

Professor M. Vukobratovic, Mihailo Pupin Institute, Belgrade, Yugoslavia

Professor Yunfeng Wang, The College of New Jersey, Ewing, USA

Professor K. Warwick, University of Reading, UK

Professor Mark H. Yim, University of Pennsylvania Philadelphia, USA

Professor Yu Zhou, SUNY Stony Brook, USA

country's rate. VAT registered subscribers should provide their VAT registration number. Orders, which must be accompanied by payment, may be sent to a bookseller, subscription agent or direct to the publishers: Cambridge University Press, The Edinburgh Building, Shaftesbury Road, Cambridge CB2 8RU, UK. Orders from the USA, Canada and Mexico should be sent to Cambridge University Press, Journals Fulfillment Department, 100 Brook Hill Drive, West Nyack, New York 10994-2133. Japanese prices for institutions are available from Kinokuniya Company Ltd, P.O. Box 55, Chitose, Tokyo 156, Japan. Prices include delivery by air.

Periodicals postage paid at New York, NY and additional mailing offices. POSTMASTER: send address changes in USA, Canada and Mexico to Robotica, Cambridge University Press, 100 Brook Hill Drive, West Nyack, New York 10994-2133.

\section{CopyING}

This journal is registered with the Copyright Clearance Center, 222 Rosewood Drive, Danvers, MA 01923. Organizations in the USA who are also registered with CCC may therefore copy material (beyond the limits permitted by sections 107 and 108 of US copyright law) subject to payment to CCC of the per-copy fee of $\$ 16.00$. This consent does not extend to multiple copying for promotional or commercial purposes. Code 0263-5747/2011/\$16.00.

ISI Tear Sheet Service, 3501 Market Street, Philadelphia, Pennsylvania 19104, USA, is authorised to supply single copies of separate articles for private use only.

Organizations authorized by the Copyright Licensing Agency may also copy material subject to the usual conditions.

For all other use, permission should be sought from Cambridge or the American Branch of Cambridge University Press.

Information on Robotica and all other Cambridge journals can be accessed via http://journals.cambridge.org/ and in North America via http://www.cambridge.org/. 